\title{
EKSTRAKSI GELATIN DARI TULANG IKAN TENGGIRI MELALUI PROSES HIDROLISIS MENGGUNAKAN LARUTAN BASA
}

\author{
GELATIN EXTRACTION FROM MACKEREL BONE BY \\ HIDROLYSIS PROCCESSES USED ALKALINE SOLUTION
}

\author{
Rizky Arcinthya Rachmania , Fatimah Nisma, Elok Mayangsari \\ Jurusan Farmasi UHAMKA, Jakarta
}

\begin{abstract}
ABSTRAK
Gelatin merupakan suatu protein yang diperoleh dari hidrolisis kolagen kulit dan tulang hewan. Penggunaan gelatin sangat luas dalam bidang industri pangan, non pangan dan farmasi. Umumnya gelatin diperoleh dari tulang atau kulit hewan mamalia, seperti sapi dan babi. Hal ini yang menjadikan gelatin dari tulang ikan tenggiri sebagai bahan alternatif untuk menghasilkan gelatin halal. Penelitian ini bertujuan membuat ekstrak gelatin dari tulang ikan tenggiri dengan menggunakan larutan $\mathrm{NaOH}$ konsentrasi 1-5\%. Parameter analisis yang diuji adalah analisis proksimat meliputi kadar air menggunakan metode thermogravimetri, kadar abu mengunakan metode drying ash, kadar nitrogen total dan kadar protein menggunakan metode Kjeldahl. Hasil penelitian diperoleh untuk kadar air sebesar $7,9568 \%$, kadar abu 1,9444\%, kadar $\mathrm{N}$ total 4,3356\% dan kadar protein $27,097 \%$. Dan rendemen terbanyak dari ekstrak gelatin diperoleh pada konsentrasi $\mathrm{NaOH}$ $5 \%$ yaitu $7,93 \%$.
\end{abstract}

Kata kunci: Gelatin, Tulang ikan tengiri, hidrolisis

\section{ABSTRACT}

Gelatin is protein that is obtained from hydrolise collagen of animal skin and bones. Gelatin has many benefit in food industry, nonfood industry and pharmacy industry. Most of gelatins were obtained from bone and skin mammals, such as cow and pork. So that, it makes gelatin from mackerel as alternaive material to produce halal gelatin. The objective of this research to make the extract gelatin from bone mackerel using $\mathrm{NaOH}$ solution concentration of 1-5\%. Analysis parameters tested were the proximate analysis include moisture content, using thermogravimetri, determination of ash content ash drying methods, as well as the determination of total nitrogen and protein content is done by using the Kjeldahl method. The results obtained for the water content of $7.9568 \%, 1.9444 \%$ ash content, total $N$ content of $4.3356 \%$ and $27.097 \%$ protein content. And the highest yield of gelatin extracts obtained at $\mathrm{NaOH}$ concentration of $5 \%$ is $7.93 \%$.

Keywords: Gelatin, bone mackerel, hydrolysis 


\section{PENDAHULUAN}

Gelatin adalah protein yang diperoleh dari hidrolisis parsial kolagen dari kulit, jaringan ikat putih dan tulang hewan. Gelatin menyerap air 5-10 kali beratnya. Gelatin larut dalam air panas dan jika didinginkan akan membentuk gel (Anonim, 1995). Gelatin memiliki sifat yang khas, yaitu berubah secara reversible dari bentuk sol (koloid) ke bentuk gel, mengembang dalam air dingin, dapat membentuk film serta mempengaruhi viskositas suatu bahan (Parker, 1982). Pengunaan gelatin sangat luas khususnya dalam bidang industri pangan maupun non pangan. Gelatin juga mempunyai banyak fungsi dan sangat aplikatif penggunaannya dalam industri pangan dan non pangan. Penggunaan gelatin dalam industri pangan misalnya, produk jeli, di industri daging dan susu dan dalam produk low fat food supplement. Pada industri non pangan gelatin digunakan misalnya pada industri pembuatan film foto (Anonim, 2008).

Bidang farmasi banyak
menggunakan gelatin dalam pembuatan kapsul lunak maupun keras dan sebagai bahan pengikat dalam sediaan tablet (Anonim, 2008). Sifat khas lainnya dari gelatin yang paling disukai oleh hampir seluruh industri makanan maupun farmasi yaitu melting in the mouth (meleleh dalam mulut), karena titik leleh gelatin antara $27-34^{\circ} \mathrm{C}$, oleh sebab itu gelatin disebut miracle food (Poppe, 1992). Gelatin juga mempunyai sifat bioadesif yang cukup baik sehingga dapat digunakan dalam sistem penghantaran mukoadesif (Chien, 1992). Sistem penghantaran mukoadesif adalah suatu sistem penghantaran obat dimana obat bersama polimer bioadesif didesain untuk dapat berkontak lebih lama dengan membran mukosa dalam saluran pencernaan (Agoes, 2001). Sistem penghantaran mukoadesif ini bertujuan untuk meningkatkan konsentrasi obat di dalam saluran pencernaan sehingga memberikan keuntungan farmakokinetik dan farmakodinamik obat (Klausener dkk., 2003).

Sumber utama gelatin yang banyak dimanfaatkan adalah berasal dari kulit dan tulang sapi atau babi. Bahan-bahan ini menimbulkan masalah, khususnya untuk negara berpenduduk mayoritas muslim, seperti Indonesia, karena babi diharamkan untuk dikonsumsi, serta isu-isu lain dari hewan mamalia terutama sapi tentang maraknya berita penyakit sapi gila ( $\mathrm{mad}$ cow disease) atau bovine spongioform encephalopathy (BSE) (Irawaty, 2005), karena kekhawatiran tersebut, maka diperlukan bahan baku alternatif lain yang melimpah, murah dan halal.

Tulang ikan dapat digunakan sebagai bahan baku alternatif sumber gelatin. Pada penelitian ini 
digunakan bahan baku pembuatan gelatin dari tulang ikan tenggiri. Tulang ikan yang diambil dapat dijadikan sebagai sumber kolagen aman dan halal yang berasal dari limbah industri pengolahan ikan. Hal ini dikarenakan pada bagian tertentu dari ikan misalnya tulang dan kulit terdapat kolagen yang kalau diperlakukan asam atau alkali dengan metode ekstraksi menyebabkan kolagen tersebut dapat dikonversi menjadi gelatin (Junianto, 2006). Pemanfaatan tulang ikan tenggiri sebagai sumber gelatin merupakan salah satu alternatif mengingat daging ikan tenggiri banyak digunakan dalam pembuatan makanan siomay, pempek, kerupuk dan makanan kaleng. Ikan tenggiri merupakan jenis ikan bertulang keras mempunyai kandungan kolagen berkisar antara $15-17 \%$ (Junianto, 2006). Tenggiri adalah nama umum bagi sekelompok ikan yang tergolong ke dalam marga scomberomorus, suku scombridae. Ikan ini merupakan kerabat dekat tuna, tongkol, makerel dan kembung (Gerry, 2000).

Ekstrak gelatin dari tulang ikan tenggiri yang diperoleh dilakukan uji analisis kualitatif dan kuantitatif berdasarkan Farmakope Indonesia edisi IV, uji kuantitatif berupa analisis proksimat diantaranya uji kadar air, kadar abu dan penetapan kadar nitrogen, dan uji kualitatif berupa organoleptis (bentuk, warna, dan bau). Analisis proksimat gelatin hasil ekstraksi dari tulang ikan tenggiri sebagai langkah awal memulai produksi gelatin dari tulang ikan yang dapat digunakan sebagai bahan dasar pembuatan kapsul atau pembuatan produk pangan maupun non pangan lain dengan sifat termomikanik yang sebanding dengan kapsul atau bahan non pangan yang terbuat dari gelatin sumber lainnya. Penelitian ini diharapkan diperoleh ekstrak gelatin dari tulang ikan tenggiri melalui proses hidrolisis dengan larutan basa dan diperoleh kadar yang optimal sehingga dapat dimanfaatkan sebagai bahan alternatif untuk produk pangan maupun produk non pangan.

\section{METODE PENELITIAN}

\section{Determinasi sampel uji}

Ikan tenggiri sebelum dilakukan penelitian, dilakukan determinasi terlebih dahulu di LIPI Oceanografi Ancol, Jakarta Utara.

\section{Pembuatan gelatin}

a. Tahap persiapan

Bahan yang digunakan adalah tulang ikan tenggiri. Tulang ikan dibersihkan dari sisa-sisa daging dan lemak yang masih menempel dengan cara direndam dengan air selama 30 menit, penghilangan lemak pada tulang efektif dilakukan pada suhu antara titik cair lemak dan suhu koagulasi albumin tulang yaitu 
antara $32-70^{\circ} \mathrm{C}$, sehingga dihasilkan kelarutan lemak yang optimum, kemudian sisa serat dan lemak yang masih menempel di tulang dibersihkan kembali dengan pisau. Tulang ikan dipotong-potong menjadi bagian yang lebih kecil yaitu ukuran sekitar $\pm 2 \mathrm{~cm}$. Tulang kemudian dibagi menjadi lima bagian yang nantinya akan direndam dalam larutan $\mathrm{NaOH}$ (1-5\%). Tulang ditimbang, masing-masing sebesar $\pm 50 \mathrm{~g}$, masa ini adalah masa sebelum perendaman $(\mathrm{Mb})$.

Setelah ditimbang tulang kemudian dimasukkan ke dalam erlenmeyer $500 \mathrm{ml}$ dan direndam dengan larutan $\mathrm{NaOH}$ dengan konsentrasi $1 \%$. Kemudian erlenmeyer ditutup dan diberi label. Hal yang sama dilakukan juga terhadap perendaman tulang dengan larutan $\mathrm{NaOH}$ konsentrasi 2-5\%. Masing-masing perbandingan tulang dengan larutan basa adalah 1:3. Proses ini disebut liming. Proses liming bertujuan untuk merusak atau memutuskan berbagai ikatan kimia yang masih ada dalam kolagen dan untuk menghilangkan atau mengurangi material lain yang tidak diinginkan, seperti protein lain dan karbohidrat (Hasan, 2007). Setelah masing-masing masa perendaman berakhir, tulang ditiriskan beberapa saat sampai tak ada cairan yang menetes. Massa tulang sesudah perendaman (Ma) ditimbang dan dicatat hasilnya. b. Tahap ekstraksi dan pengeringan

Setelah itu ossein (tulang ikan yang telah direndam dan tulang telah lunak) dalam masing-masing larutan $\mathrm{NaOH}(1-5 \%)$ dinetralkan pH-nya dengan ammonium sulfat (untuk membuang larutan $\mathrm{NaOH}$ yang masih melekat pada tulang) dengan cara mengalirkan air selama \pm 1 jam. Setelah $\mathrm{pH}$ netral, ossein tersebut ditiriskan lalu ditimbang massanya (M1). Masing-masing ossein kemudian diekstraksi dengan aquadest (1:2) menggunakan waterbath selama 5 jam pada suhu $60^{\circ} \mathrm{C}$. Selama perendaman dengan air panas dilakukan pengadukan. Setelah ekstraksi lalu tulang segera diangkat, dinginkan dan saring dengan kertas saring Whatman pada wadah berbeda. Ekstrak yang diperoleh kemudian dipekatkan dengan rotary evaporator. Pemekatan larutan gelatin untuk meningkatkan total solid larutan sehingga mempercepat proses pengeringan dengan menggunakan evaporator. Pemekatan dilakukan selama 5 jam pada suhu $70^{\circ} \mathrm{C}$ (Hasan, 2007).

Tahap terakhir adalah pengeringan gelatin pekat yang telah padat dengan menuang dalam cawan petri lalu masukkan dalam oven pada suhu $50^{\circ} \mathrm{C}$ selama 24 jam. Setelah itu didinginkan dalam desikator lalu ditimbang (Hasan, 2007). Lapisan gelatin yang terbentuk di seluruh permukaan cawan petri dikerok lalu ditumbuk 
hingga menjadi gelatin bubuk dan ditimbang (M2). Ekstrak gelatin bubuk yang diperoleh kemudian di analisis.

3. Analisis hasil

Analisa hasil dari ekstrak gelatin kering atau bubuk meliputi:

a. Analisis kualitatif (Anonim, 1995).

Pada larutan (1 dalam 100) ditambahkan trinitrifenol LP yang sebelumnya telah dicampur dengan asam klorida $3 \mathrm{~N}$ yang lebih kurang seperempat volume terbentuk endapan kuning. Pada larutan (1 dalam 100) ditambahkan larutan Kalium dikromat P (1 dalam 15) yang sebelumnya telah dicampur dengan asam klorida $3 \mathrm{~N}$ lebih kurang seperempat volume terbentuk endapan kuning.

b. Analisis kuantitatif

1) Penetapan kadar air secara termogravimetri (Anang dan Nurwantoro, 2004).

Cawan porselen dikeringkan di dalam oven pada suhu $100^{\circ} \mathrm{C}$ selama 1 jam, lalu didinginkan di dalam desikator. Cawan porselen tersebut kemudian ditimbang. Sebanyak 0,5 gram sampel dimasukkan dalam cawan porselen kering dan dikeringkan dalam oven pada suhu $105^{\circ} \mathrm{C}$ selama 24 jam hingga diperoleh berat konstan. Cawan berisi sampel tersebut didinginkan dalam desikator. Proses selanjutnya adalah penimbangan cawan yang berisi sampel setelah dikeringkan.
Kadar air bahan dihitung menggunakan rumus:

$$
\text { kadar air }=\frac{B 1-B 2}{B} \times 100 \%
$$

Keterangan:

$\mathrm{B}=$ Berat sampel $(\mathrm{g})$

B1 = Berat (sampel+cawan) sebelum dikeringkan $(\mathrm{g})$

B2 = Berat (sampel+cawan) setelah dikeringkan $(\mathrm{g})$

2) Penetapan kadar abu (drying ash ) (Nurilmala, 2006).

Cawan pengabuan dikeringkan dalam oven pada suhu $105^{\circ} \mathrm{C}$ selama 1 jam lalu didinginkan selama 15 menit dalam desikator. Cawan porselen tersebut kemudian ditimbang. Sampel sebanyak 2 gram dimasukkan dalam cawan pengabuan dan dipijarkan di atas nyala api hingga tidak berasap. Sampel dimasukkan dalam tanur pengabuan dengan suhu $600^{\circ} \mathrm{C}$ selama 6 jam. Cawan berisi sampel didinginkan dalam desikator kemudian ditimbang. Kadar abu ditentukan dengan rumus:

$$
\begin{aligned}
& \text { kadar abu(\%) } \\
& =\frac{\text { Berat abu }(\mathrm{g})}{\text { Berat sampel }(\mathrm{g})} \times 100 \%
\end{aligned}
$$

Berat $\mathrm{abu}=$ berat sampel dan cawan setelah pengabuan (g) - cawan kosong (g) 
3) Penetapan kadar nitrogen total (Anonim, 1995).

Prinsipnya adalah penentuan jumlah Nitrogen $(\mathrm{N})$ yang dikandung oleh suatu bahan dengan cara mendegradasi protein bahan organik dengan menggunakan asam sulfat pekat untuk menghasilkan nitrogen sebagai amonia, kemudian menghitung jumlah nitrogen yang terlepas sebagai amonia lalu mengkonversikan ke dalam kadar protein dengan mengalikannya dengan konstanta tertentu. Metode Kjeldahl pada dasarnya dapat dibagi menjadi tiga tahapan, yaitu proses destruksi, proses destilasi, dan tahap titrasi. Cara Kerja: (Sudarmaji, 1995)

a. Kira-kira sebanyak $500 \mathrm{mg}$ sampel ditimbang, setelah itu sampel dimasukkan ke dalam labu destruksi. Ke dalam labu ditambahkan $500 \mathrm{mg}$ selenium serta $25 \mathrm{ml} \mathrm{H}_{2} \mathrm{SO}_{4}$ pekat secara homogen. Campuran tersebut dipanaskan dengan alat destruksi suhu tinggi $\left(400^{\circ} \mathrm{C}\right)$ sampai larutan menjadi jernih dan berwarna hijau kekuningan, proses ini berlangsung di dalam ruang asam.

b. Larutan sampel yang telah terdestruksi didinginkan di desikator. Setelah larutan tersebut dingin masukkan ke dalam labu ukur, diencerkan dengan $100 \mathrm{ml}$ aquadest. Kemudian pipet $50 \mathrm{ml}$ masukkan ke dalam labu Kjeldahl tambahkan kirakira $15 \mathrm{ml} \mathrm{NaOH} \quad 30 \%$ dan ditempatkan di sebelah kiri. Kemudian alat destilasi berupa pipa kecil panjang dimasukkan ke dalamnya hingga hampir mencapai dasar tabung reaksi sehingga diharapkan proses destilasi akan berjalan maksimal (sempurna). Erlenmeyer yang berisi $5 \mathrm{ml}$ asam borat $3 \%+$ BCG-MR (campuran bromcresol green dan methyl red) ditempatkan di bagian kanan dalam alat Kjeldahl. Setelah ditambah BCG-MR, larutan akan berwarna merah muda karena berada dalam kondisi asam. Ammonia yang dibebaskan selanjutnya akan ditangkap oleh asam borat $3 \%$ dalam jumlah yang berlebihan. Agar supaya kontak antara asam dan ammonia lebih baik maka diusahakan ujung tabung destilasi tercelup sedalam mungkin dalam asam.

c. Proses terakhir adalah proses titrasi. Labu erlenmeyer yang berisi hasil destilat tersebut diambil dan dititrasi kembali dengan menggunakan larutan $\mathrm{HCl} 0.1 \mathrm{~N}$. Proses titrasi berhenti setelah terjadi perubahan warna merah muda seulas yang tidak hilang selama 30 detik menggunakan indikator PP yang menandakan titik akhir titrasi. Volume $\mathrm{HCl}$ dicatat. Adapun rumus penentuan kadar $\% \mathrm{~N}$ dan $\%$ protein sebagai berikut:

$$
\begin{aligned}
& \% \mathrm{~N} \\
& =\frac{\mathrm{Fp} \times \mathrm{Vt} \mathrm{HCl} \times 14,007 \times \mathrm{N} \mathrm{HCl}}{\text { Berat sampel }} \times 100 \% \\
& \% \text { Protein }=\% \mathrm{~N} \times 6.25(\mathrm{FK})
\end{aligned}
$$

Keterangan:

$\mathrm{Fp}=$ Faktor pengencer

$\mathrm{Vt}=$ Volume" titran $\mathrm{HCl}$ 
$\mathrm{N} \mathrm{HCl}=$ Normalitas $\mathrm{HCl}$

$14,007=$ Berat atom Nitrogen

$\mathrm{FK}=$ Faktor Konversi prtein makanan

$\% \mathrm{~N}=$ Kadar Nitrogen total

*Protein alamiah mengandung unsur

$\mathrm{N}$ rata-rata $16 \%$ (dalam protein murni). $\mathrm{FK}=100 / 16=6,25$

\section{HASIL DAN PEMBAHASAN}

1. Determinasi sampel uji

Berdasarkan hasil determinasi

dari LIPI ikan tenggiri yang digunakan dalam penelitian ini memiliki ciri-ciri morfologinya yaitu duri keras sirip dorsal, duri lunak sirip dorsal, mata tidak ada selaput, gigi tajam menyerupai pisau berbentuk segitiga, moncong mulut lebih pendek dari panjang kepala, lateral line membengkok ke arah bawah sampai ujung sirip dorsal yang kedua dan ada guratan di pangkal ekor. Oleh karena itu, dari data hasil determinasi LIPI ikan tenggiri

(Scomberomorus commerson) yang peneliti gunakan tergolong ke dalam marga scomberomorus, suku scombridae.

2. Rendemen gelatin

Tulang hewan terdiri atas serat kolagen. Ikatan pada kolagen akan terputus jika terkena asam atau basa kuat, sehingga membentuk uraian yang dapat larut dalam air panas. Untuk mendapatkan ekstrak gelatin dari tulang diperlukan proses hidrolisis kolagen dengan cara ekstraksi dengan air panas yang dikombinasi dengan perlakuan asam atau alkali (Tourtellote, 1980). Berdasarkan hasil penelitian, diperoleh nilai rendemen ekstrak gelatin yang berkisar antara 3,44\% 7,93\%. Hasil rendemen gelatin dalam bentuk histogram dapat dilihat pada Gambar 1. Peningkatan konsentrasi $\mathrm{NaOH}$ memberikan efek hidrolisis yang semakin efektif, yaitu ossein yang terbentuk lebih optimal, dan berpotensi mengalami proses lebih lanjut membentuk gelatin. Hal ini dapat mengakibatkan rendemen ekstrak gelatin meningkat pada perendaman dengan konsentrasi $\mathrm{NaOH}$ tertinggi. Tingginya rendemen yang dihasilkan diduga juga akibat adanya ion $\mathrm{OH}^{-}$yang menghidrolisis kolagen dari rantai triple helix menjadi rantai tunggal sehingga menghasilkan gelatin tinggi (Nurilmala, 2006).

Ekstraksi dilakukan pada suhu 50-70 ${ }^{\circ} \mathrm{C}$. Suhu optimum untuk ekstraksi di atas waterbath adalah $50,60,70^{\circ} \mathrm{C}$, karena suhu terlalu rendah dan terlalu tinggi menghasilkan rendemen rendah dan kualitas gelatin juga rendah. Pemanasan kolagen secara bertahap akan menyebabkan struktur rusak dan rantai-rantai akan terpisah (Nurilmala, 2006).

a. Uji organoleptis

Hasil uji organoleptik ekstrak gelatin dengan perlakuan $\mathrm{NaOH} 1-5 \%$ dan suhu $70^{\circ} \mathrm{C}$ terhadap parameter 
bentuk, warna, dan bau dapat dilihat pada tabel I. Mengacu pada Farmakope Indonesia edisi IV bahwa pemerian gelatin adalah serbuk berwarna kuning agak putih atau coklat kekuningan. Karena telah mengalami pemekatan dan penyaringan terhadap ekstrak gelatin, proses penyaringan bertujuan untuk memisahkan zat-zat organik seperti lemak dan karbohidrat yang tidak larut dan menandakan kemurnian dari gelatin. Gelatin komersil tidak berbau sedangkan gelatin tulang ikan tenggiri agak berbau khas (Sudarmaji, 1995). Bau ikan pada gelatin tulang ikan tenggiri diduga disebabkan oleh unsur nitrogen yang terikat pada asam-asam amino pada kolagen atau gelatin tulang ikan tenggiri.

b. Uji kualitatif (Anonim, 1995).

Hasil uji kualitatif ekstrak kering sampel gelatin pada rendemen tertinggi (konsentrasi larutan $\mathrm{NaOH} 5 \%$ ) dengan hasil yang terlihat pada Tabel II.

Larutan gelatin bila ditambahkan kalium dikromat akan terbentuk endapan kuning, hal ini menunjukkan postif gelatin, dan larutan gelatin bila ditambahkan larutan Trinitrifenol maka terbentuk endapan kuning, yang menunjukkan positif gelatin. Bila dalam suatu larutan protein ditambahkan garam kalium dikromat maka daya larut protein akan berkurang akibatnya protein akan terpisah sebagai endapan. Peristiwa pemisahan protein ini disebut salting out (Lehninger, 1997).

c. Uji kuantitatif

1) Kadar air

Air dapat mempengaruhi penampakan, tekstur, cita rasa serta mutu bahan pangan (Winarno, 2002). Kadar air gelatin akan berpengaruh terhadap daya simpan, karena erat kaitannya dengan aktivitas metabolisme yang terjadi selama gelatin tersebut disimpan seperti aktivitas enzim, aktivitas mikroba dan aktivitas kimiawi, yaitu terjadinya ketengikan dan reaksi-reaksi non enzimatik sehingga menimbulkan perubahan sifat-sifat organoleptik dan nilai mutunya.

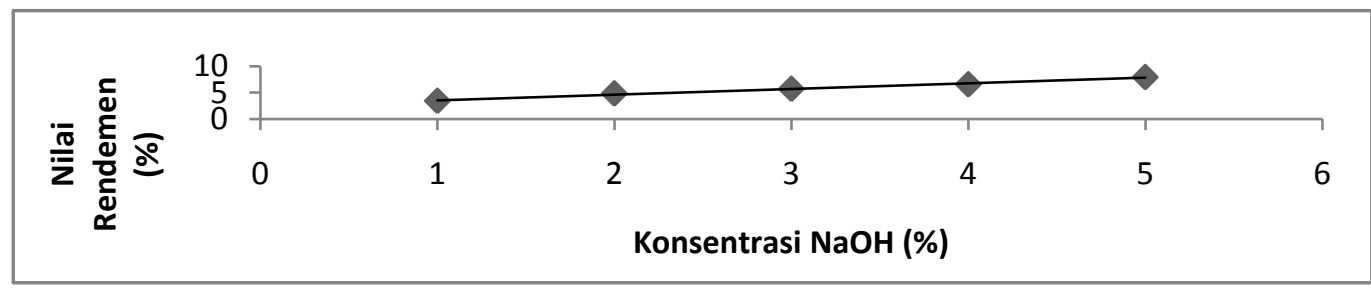

Gambar 1. Histogram nilai rendemen gelatin tulang ikan tenggiri (Scomberomorus commerson) 
Tabel I. Data Hasil Analisis Karakteristik Gelatin Tulang Ikan Tenggiri dengan NaOH 1-5\%.

\begin{tabular}{lclll}
\hline \multicolumn{5}{c}{ Hasil pengamatan } \\
\hline No. & Kadar NaOH (\%) & Bentuk & Warna & Bau \\
\hline 1. & 1 & Serbuk & Coklat kekuningan & Khas \\
2. & 2 & Serbuk & Coklat kekuningan & Khas \\
3. & 3 & Serbuk & Coklat kekuningan & Khas \\
4. & 4 & Serbuk & Coklat kekuningan & Khas \\
5. & 5 & Serbuk & Coklat kekuningan & Khas \\
\hline
\end{tabular}

Tabel II. Uji Kualitatif (Identifikasi Gelatin)

\begin{tabular}{lll}
\hline No. & Reagen & Hasil \\
\hline 1. & Kalium dikromat & Endapan kuning \\
2. & Trinitrifenol & Endapan kuning \\
\hline
\end{tabular}

Kadar air dari tulang ikan tenggiri diperoleh $7,9568 \%$, hasil kadar air dapat dilihat pada Tabel IV. Tinggi rendahnya kadar air suatu bahan ditentukan oleh sifat dan kemampuan bahan dalam menarik air, serta proses pengeringan yang dilakukan terhadap bahan tersebut (Hasan, 2007). Namun kadar air yang diperoleh ini telah memenuhi syarat SNI (06-3735-1995) (Tabel. III), yaitu maksimal $16 \%$ untuk ikan tenggiri dan tuna.

\section{2) Kadar abu}

Kadar abu pada ekstrak gelatin tulang ikan tenggiri pada tabel IV telah memenuhi syarat SNI (063735-1995) yaitu 1,93\%, kadar abu maksimum menurut SNI (06-3735$1995)$ yaitu $3,25 \%$. Nilai kadar abu suatu bahan pangan menunjukkan besarnya jumlah mineral yang terkandung dalam bahan pangan tersebut. Penentuan kadar abu dimaksudkan untuk mengetahui kandungan komponen yang tidak mudah menguap (komponen anorganik atau garam mineral) yang tetap tinggal pada pembakaran dan pemijaran senyawa organik (Nurilmala, 2006). Semakin rendah kadar abu suatu bahan, maka semakin tinggi kemurniannya. Tinggi rendahnya kadar abu suatu bahan antara lain disebabkan oleh kandungan mineral yang berbeda pada sumber bahan baku dan juga dapat dipengaruhi oleh proses demineralisasi pada saat pembuatan (Sudarmaji, 1995).

Tabel III. Standar Mutu Gelatin menurut SNI (06 -3735-1995)

\begin{tabular}{lll}
\hline No. & Parameter (\%) & Gelatin SNI (1995) \\
\hline 1. & Kadar air & Maks 16\% \\
2. & Kadar Abu & Maks 3.25\% \\
3. & Kadar Protein & - \\
\hline
\end{tabular}


Tabel IV. Data Hasil Analisis Kuantitatif Ekstrak Gelatin

\begin{tabular}{ccc}
\hline No. & Pengujian & Hasil $(\%)$ \\
\hline 1. & Kadar air & 7,95 \\
2. & Kadar abu & 1,94 \\
\hline
\end{tabular}

Tabel V. Data Hasil Penetapan Kadar N Total dan Kadar Protein pada Ekstrak Gelatin

\begin{tabular}{cccc}
\hline No. & Konsentrasi NaOH $(\%)$ & Kadar N Total $(\%)$ & Kadar Protein $(\%)$ \\
\hline 1. & 1 & 4,27 & 26,74 \\
2. & 2 & 4,28 & 26,75 \\
3. & 3 & 4,27 & 26,73 \\
4. & 4 & 4,33 & 27,108 \\
5. & 5 & 4,33 & 27,097 \\
\hline
\end{tabular}

rendemen terendah yang dihasilkan

3) Penetapan kadar nitrogen

Kadar protein yang dianalisa dengan metoda Kjeldahl dapat digunakan untuk menentukan jumlah nitrogen yang dikandung oleh suatu bahan (Sudarmaji, 1995). Gelatin diperoleh dari hidrolisis atau penguraian kolagen dengan panas (Lehninger, 1997). Dari hasil penelitian ini persen kadar nitrogen pada $\mathrm{NaOH} 5 \%$ sebesar $4,33 \%$ dan persen kadar protein yang diperoleh sebesar 27,097\% (Tabel IV). Kadar protein yang diperoleh disebabkan pemanasan yang dilakukan secara berlebihan atau waktu yang lama, sehingga dapat mengakibatkan jumlah protein bertambah hal tersebut karena protein terdisosiasi dan ketika terikat kembali terbentuk senyawa baru dalam protein.

\section{KESIMPULAN}

Hasil penelitian menunjukkan bahwa rendemen gelatin tertinggi dihasilkan pada perendaman tulang dengan larutan $\mathrm{NaOH} 5 \%$ selama 2 hari pada suhu $70^{\circ} \mathrm{C}$, sedangkan perendaman dengan larutan $\mathrm{NaOH}$ $1 \%$ selama 25 hari suhu $70^{\circ} \mathrm{C}$. Hasil analisis proksimat dari ekstrak gelatin tulang ikan tenggiri dengan perlakuan basa $\mathrm{NaOH}$ diperoleh kadar air sebesar 7,95\%, kadar abu $1,94 \%$ dan kadar nitrogen total pada konsentrasi larutan $\mathrm{NaOH} \quad 5 \%$ sebesar $4,33 \%$ dan persen kadar protein sebesar $27,097 \%$.

\section{DAFTAR PUSTAKA}

Agoes, G., 2001, Sistem Penghantaran Obat Mukoadesif Desain Bentuk Sediaan Obat, Teknologi Farmasi Program Pasca Sarjana Institut Teknologi Bandung :9.

Anang, M. dan Nurwantoro, 2004, Analisis Pangan-Teknologi Hasil Ternak, Universitas Diponegoro, Semarang.

Anonim, 1995, Farmakope Indonesia. Ed. 4. Departemen Kesehatan Republik Indonesia. Dirjen POM. Jakarta :404, 964.

Anonim, 2008, Gelatin halal gelatin haram, Jurnal Halal (LPPOM MUI) on line, 
http://www.indohalal.com.doc_h alal2.html.

Chien,Y.W., 1992, Novel Drug Delivery System. 2nd ed., New York: Marcel Dekker Inc. :173.

Gerry, A., 2000, Marine Fishes of South East Asia, Australia.

Hasan, 2007, Studi Ekstraksi pada Proses Pembuatan Gelatin Tipe $B$ dari Kulit Sapi, IPB, Bogor.

Irawaty, 2005, Pengaruh Penambahan Konsentrasi Asam Asetat pada Pembuatan Gelatin dari Ikan Gurami (Osphronemus gouramy lac), Jakarta.

Junianto, 2006, Produksi Gelatin dari Tulang Ikan dan Pemanfaatannya Sebagai Bahan Dasar Pembuatan Cangkang Kapsul, Laporan Penelitian, Unpad, Bandung.

Klausener, E.A., Lavy,E., Friedman,L., Hoffman,A., 2003, Expandable Gastro Retentive Dosage Form. Elsevier. Journal of Controlled Release; 90 :141.

Lehninger,A.L., 1997, Dasar-dasar Biokimia, Jilid I, Penerjemah: Thenawijaya M., Penerbit: Erlangga, Jakarta : 107-108, 181182.

Nurilmala, M., 2006, Perbaikan Nilai Tambah Limbah Tulang Ikan Tuna (Thunnus sp) Menjadi Gelatin serta Analisis FisikaKimia, Laporan Penelitian, IPB, Bogor.
Parker,A.L., 1982, Principles of Biochemistry, Worth Publishers, Inc., Sparkas, Maryland.

Poppe,J., 1992, Gelatin di dalam Thickening and Gelling Agent for Food, ed: A. Imeson, Academic Press, New York.

Sudarmaji,S., 1995, Prosedur Analisa Bahan Makanan Pertanian, Liberty, Yogyakarta.

Tourtellote,P., 1980, Encyclopedia of Science and Technology, Mc. Graw Hill Book Co., New York.

Winarno,F.G., 2002, Kimia Pangan dan Gizi, PT Gramedia Pustaka Utama, Jakarta. 